Chirurgia (2020) 115: 520-525

No. 4, July - August

Copyright@ Celsius

http://dx.doi.org/10.21614/chirurgia.115.4.520

\title{
Laparoscopic Central Pancreatectomy with Pancreato- Gastric Anastomosis for Pancreatic Cystadenoma
}

\author{
Cristian Liviu Cioltean ${ }^{1}$, Adrian Bartoș ${ }^{1,2^{*}}$, Stoian Raluca ${ }^{1,3}$, Ioana lancu ${ }^{1,3}$, Caius Breazu ${ }^{1,4}$, Cornel lancu', \\ Dana Bartoș 1,3 \\ ${ }^{1}$ Regional Institute of Gastroenterology and Hepatology, Department of Surgery, Cluj-Napoca, Romania \\ 2"Iuliu Hațieganu” University of Medicine and Pharmacy, Department of Surgery, Cluj-Napoca, Romania \\ 3"Iuliu Hațieganu" University of Medicine and Pharmacy, Anatomy and Embryology Department, Cluj-Napoca, Romania \\ ${ }^{4}$ Regional Institute of Gastroenterology and Hepatology, Department of Anesthesiology and Intensive Care, Cluj-Napoca, Romania
}

*Corresponding author:

Adrian Bartoș, MD

Regional Institute of Gastroenterology

and Hepatology, Department of

Surgery, Cluj-Napoca, Romania

Croitorilor Street, no. 19-21

E-mail: bartos.adi@gmail.com

\section{Rezumat}

Pancreatectomie centrală laparoscopică cu anastomoză pancreatogastrică pentru chistadenom pancreatic

Vă prezentăm cazul unei femei de 42 de ani, diagnosticată cu o leziune pancreatică chistică, sugestivă pentru un chistadenom seros de 27/13 mm. Diagnosticul a fost stabilit prin examenul CT abdominal şi eco-endoscopie. Pacienta a fost îndrumată către serviciul de chirurgie pentru intervenție chirurgicală. Etiologia benignă sugerată de imagistică şi dorința de a prezerva splina împreună cu o parte cât mai mare a parenchimului pancreatic, a indicat efectuarea unei pancreatectomii centrale laparoscopice $\mathrm{cu}$ anastomozarea bontului distal pancreatic cu stomacul. Autorii au revizuit publicațiile naționale şi internaționale legate de indicațiile acestei intervenții chirurgicale minim invazive.

Cuvinte cheie: pancreatectomie centrală laparoscopică, chistadenom seros pancreatic, anastomoză pancreato-gastrică

\section{Abstract}

We present the case of a 42-year-old woman diagnosed with a cystic pancreatic lesion, suggestive of a serous cystadenoma of $27 / 13 \mathrm{~mm}$. The diagnosis was established by the examination of abdominal CT and eco-endoscopy. The patient was referred to the surgery department for treatment. The benign etiology suggested 
by imaging and the desire to preserve the spleen along with as much of the pancreatic parenchyma, indicated a laparoscopic central pancreatectomy with a anastomosis between the distal pancreatic stump and the stomach. The authors reviewed the national and international publications related to the indications of this minimally invasive surgery.

Key words: laparoscopic central pancreatectomy, serous cystadenoma of the pancreas, pancreatogastric anastomosis

\section{Introduction}

Central pancreatectomy (CP) is a surgical approach which have the advantage of preserving pancreatic parenchyma and can be used as a good alternative to major pancreatic resections, such as distal pancreatectomy (DP). In published studies, CP was performed for benign lesions (neuroendocrine tumors, pancreatic cystadenomas, small intraparenchymatous tumors not suitable for enucleation) and for low-grade malignant lesions (mucosal cystic neoplasms, intraductal papillary mucinous neoplasms, solid pseudopapillary neoplasms) located in the proximal body of the pancreas (1). Central pancreatectomy decreases the morbidity associated with major pancreatic resections, with a lower incidence of pancreatic insufficiency, both endocrine and exocrine functions. It also decreases the risk of post-splenectomy infection (2).

\section{Case Report}

We present the case of a 42 years old patient with history of laparoscopic cholecystectomy for gallbladder lithiasis, serous liver cysts, erythematous gastritis, cervical disc herniation and left anexial cyst, which was presented in the gastroenterology service for extended investigation after being incidentally ultrasound diagnosed with a pancreatic cystic tumor.

Examination of the abdominal and pelvic area with contrast enhanced CT revealed at the level of the pancreatic isthmus a multilocular cystic tumor with inside septa capturing substance of contrast and polylobate contour, having the most likely significance of the cystadenoma without completely excluding a mucinous cyst. For that it is decided to perform an endoscopic ultrasound that detects a tumor of approximately $27 / 13 \mathrm{~mm}$, polycystic aspect, with multiple septa and parenchymal component, without having communication with the Wirsung duct. The tumor marker CA 19-9 had preoperative values of $25.1 \mathrm{U} / \mathrm{mL}$ (normal values being between 0-37 U/mL).

Due to the presence of the symptoms, the age of the patient and the benign character of the tumor, it is decided to perform a central pancreatectomy by laparoscopic approach.

The supra-umbilical optical trocar and 4 working trocars are used, two on the left flank and two on the right flank. The entry into the omental bursa is performed by the sectioning of the gastrocolic ligament (Fig. 1) and the pancreatic tumor is exposed, confirmed by the laparoscopic intraoperative ultrasound, of about $2 / 3 \mathrm{~cm}$, with mixed component (parenchymatous / cystic).

The dissection of the inferior margin of the pancreas is performed with the exposure of the porto-mesenteric axis (Fig. 2), followed by the transection of the pancreatic parenchyma with $60 \mathrm{~mm}$ white endo GIA stapler, with gradual compression applied (for the proximal stump) (Fig. 3) and with Harmonic device (for the distal stump) (Fig. D). The surgery is continued with a gastrotomy on the anterior face of the stomach and a pancreato-gastric anastomosis (by telescoping the pancreatic stump in to the stomach) with a monofilament sero-muscular purse string at the level of the gastrotomy, on the posterior face of the stomach, followed by the application of separate silk sutures (Fig. 5).

Postoperative outcome was marked by the 


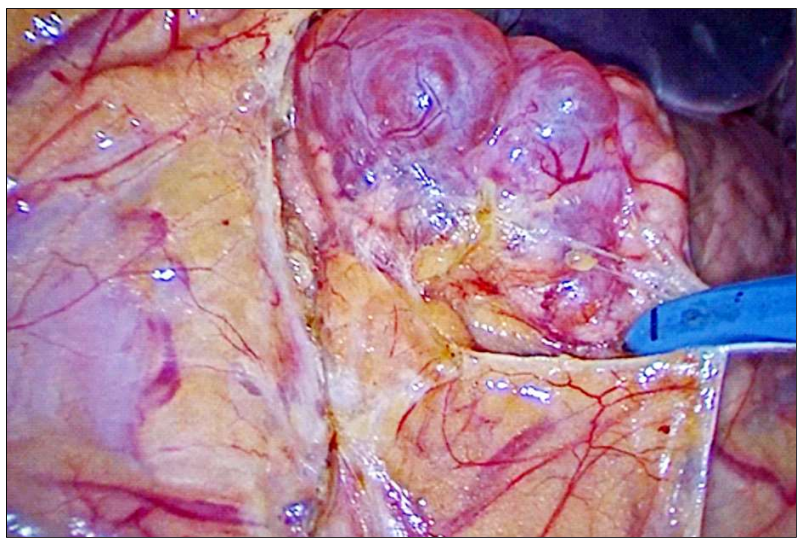

Figure 1. Exposure of the pancreatic tumor after entering the omental pouch

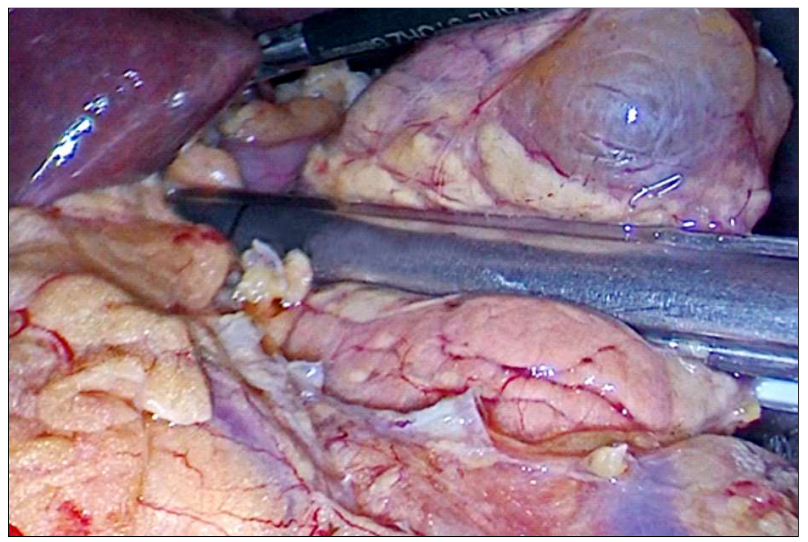

Figure 3. Pancreatic transection using linear Stapler (proximal stump)

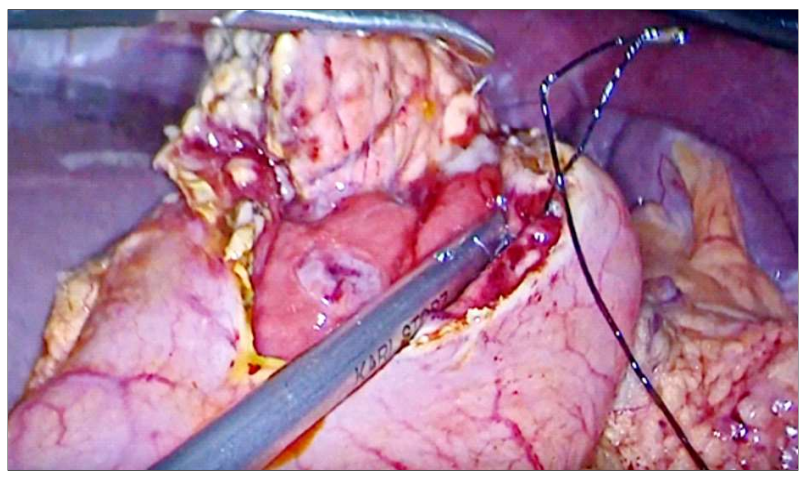

Figure 5. Pancreato-gastric anastomosis

installation of an intense abdominal pain syndrome, 48 hours after surgery. Biologically, amylases with values of $449 \mathrm{U} / \mathrm{l}$ were detected (reference values between 30-100 U / l) and lipase with values of $824 \mathrm{U} / \mathrm{l}$ (reference values between $0-60 \mathrm{U} / \mathrm{l}$ ), which is why it is

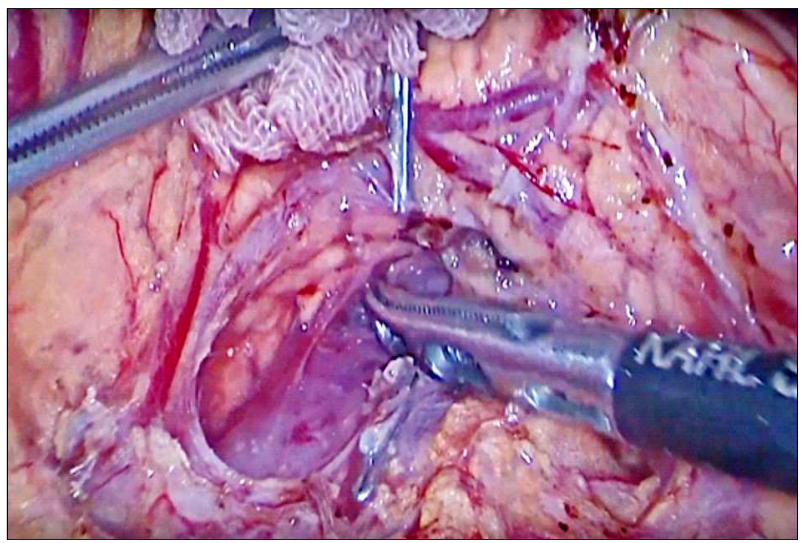

Figure 2. Retropancreatic dissection of portal vein

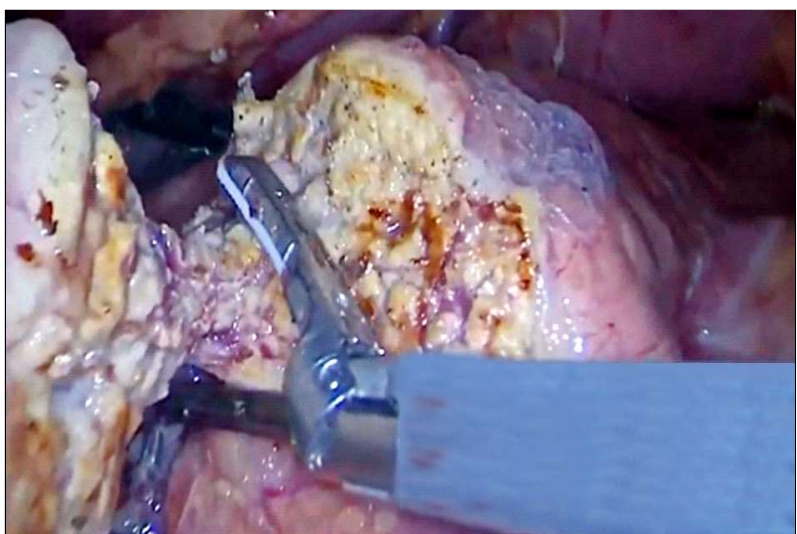

Figure 4. Pancreatic transection using the Harmonic device (distal stump)

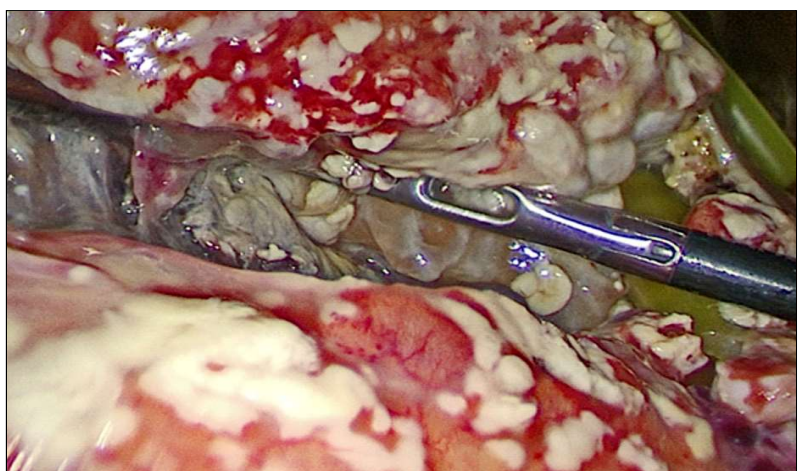

Figure 6. The appearance of necrotic pancreatitis on day 2 postoperatively (at the level of proximal pancreatic stump)

decided to perform an exploratory laparoscopy that detects acute necrotic pancreatitis (Fig. 6). The surgery was limited on exploration with confirmation that the pancreatogastric anastomosis was without leaks and the 
intraperitoneal drains are proper situated. Subsequent evolution is slowly favorable under hydro-electrolytic, antibiotic, antifungal and analgesic treatment. There were no other evolutionary complications of pancreatitis, with no organ dysfunction.

The patient is discharged on day 15 postoperatively with good general condition, with acute pancreatitis episode in remission. The histopathological result of the surgical specimen confirmed the pancreatic serous cystadenoma.

After a 12-month follow-up period, the patient remains asymptomatic, without exocrine or endocrine pancreatic insufficiency and was not hospitalized as a consequence of the surgery.

\section{Discussions}

The common use of imaging examinations (ultrasonography and CT) as diagnostic techniques has led to an increase in the incidental discovery of benign pancreatic lesions, which are generally asymptomatic and present a new challenge in terms of management and follow-up.

Regarding the treatment to the treatment of benign lesions of the isthmus and of the proximal body of the pancreas that cannot be treated by enucleation (large lesions or tumors near the Wirsung canal), the surgical techniques are distal pancreatectomy (DP) or central pancreatectomy $(\mathrm{CP})(3,4)$.

$\mathrm{DP}$ require complete resection of the body and tail of the pancreas; the CP permit the preservation of the distal pancreas, without the requirement for splenectomy (5).

CP, which was first performed by Dagradi and Serio, consists of pancreatic isthmus resection, followed by anastomosis of the distal pancreas with the stomach or jejunum (4). Although reported since 1984, with the first publications appearing in the 2000s, their number has remained low (6). In the systematic review, recently published, in 963 $\mathrm{CP}$ operations performed before the end of 2010 a complication rate of $45.3 \%$ and a mortality rate of $0.8 \%$ were reported. The incidence of exocrine and endocrine insufficiency was very low. The most frequent indications for $\mathrm{CP}$ were endocrine tumors followed by cystic tumors (7-8).

There are numerous studies that compared both procedures (CP versus DP) and showed a higher incidence of short-term morbidity associated with CP. Between the complications to be noted is the possibility of developing pancreatic fistula, of about $30-40 \%$ (4). Regarding the risk of pancreatic leak associated with the type of pancreatic anastomosis, the cumulative incidence of fistula appears to be higher in pancreatojejunostomy than in pancreato-gastrostomy. However, the first procedure has a lower risk of exocrine insufficiency (12). The risk of re-intervention for fistula is low (about 4\%), while conservative management has favorable results $(1,10)$.

$\mathrm{CP}$ has been shown to lower intraoperative blood loss, but is associated with a higher time of surgery, which is related to the carefulness required in this type of procedure $(11,12)$.

When assessing long-term outcomes, it is worth mentioning the benefit of $\mathrm{CP}$ in maintaining pancreatic function. According to the meta-analysis performed by Iacono et al. in 2013, the risk of endocrine insufficiency at $\mathrm{CP}$ was $5.5 \%$ compared to $23.6 \%$ in DP (2). Regarding exocrine function, the percentage would be $11.9 \%$ compared to $19.1 \%$ (2).

Post-operative pancreatitis is a less frequent but very serious surgical complication, with often fatal results. This is most often seen after surgery on the pancreas itself, but in rare cases it has also been described after surgical procedures on organs far removed from the pancreas (13). The following factors are involved in the onset of postoperative pancreatitis: direct mechanical injury to the pancreas and especially of the pancreatic ducts, vascular disorders, spasm of the Oddi sphincter and stagnation of the duodenal content. The question arises whether the use of the stapler or ultrasound dissector could increase the incidence of pancreatitis or pancreatic fistula (14). There are some studies which indicate that the ultrasonically activated scalpel is an effective tool for cutting 
the pancreas in biliary-pancreatic surgery. Sugo et al showed that the use of the ultrasonically activated scalpel was found to reduce the incidence of pancreatic fistula in distal pancreatectomy (14). Recently, stapling closure has become a popular method in DP and CP due to its simplicity and safety compared with the conventional suture method. Some studies insist that the stapler is a safe method (15). Pancreatic fistula rate and postoperative pancreatitis incidence increased as pancreas thickness increased. Because the compression effect is a critical point in postoperative pancreatic fistula development after DP with endoscopic stapler, it is important to choose the optimal stapler which will compress not too strongly and not to weakly (16).

According to this idea, there are authors who recommend the use of cartdriges with high staples even if the risk of bleeding is higher (17).

Gradual compression is also a key element during the application of the stapler, as sudden shedding of the parenchyma can lead to a risk of acute postoperative pancreatitis (18).

In our case, due to the reduced consistency of the pancreatic parenchyma and the reduced thickness of the pancreatic body, we opted for mechanical transection with a vascular stapler (white cartridge). Although the rules mentioned above were respected and there were no other incidents, acute pancreatitis of the proximal pancreatic stump was a postoperative complication, which is why we consider that this step remains a vulnerability of this procedure and should be treated with caution.

\section{Conclusions}

Serous cystadenoma is a rare and benign tumor, which occurs mainly in women and is usually asymptomatic. It represents approximately $25 \%$ of the cystic tumors of the pancreas, the diagnosis being established by abdominal CT and superior digestive endoscopic ultrasound. Due to the difficulty of assessing the benignity and the risk of malignant transformation, the surgical treatment of all pancreatic cystic tumors is recommended.

Central pancreatectomy is a feasible and safe surgical technique for benign or low malignancies (pancreatic cystic lesions or neuroendocrine tumors) and its aim is to reduce the risk of developing endocrine or exocrine pancreatic insufficiency by preserving as much pancreatic tissue. The laparoscopic approach has the advantages of lower perioperative pain, lower hospitalization time, lower blood loss. Main complications after laparoscopic central pancreatectomy are pancreatic fistula and acute pancreatitis. In this case, the advantage of the minimally invasive technique used for pancreatic resection was the possibility to perform a second look (also by laparoscopic approach) into the abdominal cavity at 2 days after the main surgery. The laparoscopic approach established the diagnosis of a necrotic pancreatitis at the level of proximal pancreatic stump, indicated a conservative treatment and relieved the patient of an exploratory laparotomy.

\section{Conflict of Interest}

The authors declare no conflicts of interests.

\section{References}

1. Beger HG, Siech M, Poch B, Mayer B, Schoenberg MH. Limited surgery for benign tumours of the pancreas: a systematic review. World J Surg. 2015;39(6):1557-66.

2. lacono C, Verlato G, Ruzzenente A, Campagnaro T, Bacchelli C, Valdegamberi $A$, et al. Systematic review of central pancreatectomy and meta-analysis of central versus distal pancreatectomy. $\mathrm{Br} \mathrm{J}$ Surg. 2013;100(7):873-85.

3. Goudard Y, Gaujoux S, Dokmak S, Cros J, Couvelard A, Palazzo M, et al. Reappraisal of central pancreatectomy a 12-year singlecenter experience. JAMA Surg. 2014;149(4):356-63.

4. Iacono C, Ruzzenente A, Bortolasi L, Guglielmi A. Central pancreatectomy: the Dagradi Serio lacono operation. Evolution of a surgical technique from the pioneers to the robotic approach. World J Gastroenterol. 2014;20(42):15674-81.

5. Tagaya N, Ishikawa K, Kubota K. Spleen-preserving laparoscopic distal pancreatectomy with conservation of the splenic artery and vein for a large insulinoma. Surg Endosc. 2002;16(1):217-8.

6. Iacono C, Bortolasi L, Facci E, Nifosi F, Pachera S, Ruzzenente A, et al. The Dagradi-Serio-lacono operation central pancreatectomy. J Gastrointest Surg. 2007;11(3):364-76.

7. Goudard Y, Gaujoux S, Dokmak S, Cros J, Couvelard A, Palazzo M, et al. Reappraisal of central pancreatectomy a 12-year singlecenter experience. JAMA Surg. 2014;149(4):356-63.

8. Iacono $\mathrm{C}$, Bortolasi L, Serio $\mathrm{G}$. Is there a place for central pancreatectomy in pancreatic surgery? J Gastrointest Surg. 1998;2(6): 509-16; discussion 16-7. 
9. Yin WY. The role of surgery in pancreatic pseudocyst. Hepatogastroenterology. 2005;52(64):1266-73.

10. Javed AA, Aziz K, Bagante F, Wolfgang CL. Pancreatic Fistula and Delayed Gastric Emptying After Pancreatectomy: Where do We Stand? Indian J Surg. 2015;77(5):409-25.

11. Bilimoria KY, Bentrem DJ, Ko CY, Ritchey J, Stewart AK, Winchester DP, et al. Validation of the 6th edition AJCC Pancreatic Cancer Staging System: report from the National Cancer Database. Cancer. 2007;110(4):738-44.

12. Yekebas EF, Wolfram L, Cataldegirmen G, Habermann CR, Bogoevski D, Koenig AM, et al. Postpancreatectomy hemorrhage: diagnosis and treatment: an analysis in 1669 consecutive pancreatic resections. Ann Surg. 2007;246(2):269-80.

13. Bannone E, Andrianello S, Marchegiani G, Masini G, Malleo G, Bassi C, et al. Postoperative Acute Pancreatitis Following Pancreaticoduodenectomy: A Determinant of Fistula Potentially Driven by the Intraoperative Fluid Management. Ann Surg. 2018.
14. Sugo $H$, Mikami $Y$, Matsumoto $F$, Tsumura $H$, Watanabe $Y$, Futagawa S. Comparison of ultrasonically activated scalpel versus conventional division for the pancreas in distal pancreatectomy. J Hepatobiliary Pancreat Surg. 2001;8(4):349-52.

15. Kim H, Jang JY, Son D, Lee S, Han Y, Shin YC, et al. Optimal stapler cartridge selection according to the thickness of the pancreas in distal pancreatectomy. Medicine (Baltimore). 2016; 95(35):e4441.

16. Facy 0 , Chalumeau $C$, Poussier $M$, Binquet $C$, Rat $P$, OrtegaDeballon P. Diagnosis of postoperative pancreatic fistula. $\mathrm{Br} \mathrm{J}$ Surg. 2012;99(8):1072-5.

17. Kim $H$, Jang JY, Son D, et al. Optimal stapler cartridge selection according to the thickness of the pancreas in distal pancreatectomy. Medicine (Baltimore). 2016;95(35)

18. Asbun HJ, Stauffer JA. Laparoscopic approach to distal and subtotal pancreatectomy: a clockwise technique. Surg Endosc. 2011;25(8):2643-9. 